\title{
THE PHILOSOPHICAL FOUNDATIONS OF THE RESEARCHES OF THE INCLUSIVE EDUCATION
}

\author{
HRYHORII VASIANOVYCH, OLENA BUDNYK
}

\begin{abstract}
In the article on the basis of primary sources the philosophical foundations of the modern inclusive education are examined. The content description of the idea "inclusive education" is presented, the necessity of its implementation is proved. It is focused on two basic philosophical foundations of its development: personalism and intuitionism. Such an approach is caused by the fact that in modern studies on the above-mentioned range of problems are mainly dominated by rationalist methodological approaches, in contrast with the irrationalistic theories are often out of the attention. In our analysis and interpretation, the philosophy of personalism plays an important methodological role because it helps clarify the essence of the uniqueness and originality of each child with special needs and to determine the real ways of her spiritual and psychophysical development. The philosophy of intuitionalism focuses on the study of issues related to the formation of consciousness of a person with special needs. Therefore, the authors proved the necessity of using the intuitive method of research, which allows to promote the communication of subjects of interaction actively, to reveal their spiritual potential, to perform the search for ways of forming thinking in children with special needs, use the language, culture and art at the same time and in an active way.
\end{abstract}

Keywords: inclusive education, philosophy of personalism, philosophy of intuitionalism, human center, childhood center, person with special needs, educational process, philosophy of inclusion.

\section{INTRODUCTION}

Today it becomes more and more obvious that education affects absolutely all spheres of human life and activity. Therefore, it requires instant and radical changes. We emphasize: not only so-called changes, purely formal, and those that would allow education to rise to a new level of quality (selfidentity), but at the same time, would provide an opportunity to answer to the challenges which are put by a person and a society. Instead, we are observing significant crisis phenomena in the education, which are produced not only by the imperfect development of a particular society and, more widely, the globalized world (the level of general), but also the level of individual, personal (the level of a special, individual).

How persuasive Jacqueline Russ argues: "The crisis of education ... is at the heart of our problems". According to the point of view of a scientist the style of education, which leaves the subject helpless and unable to create his life is prevailing today. "Today we are surviving a crisis of education, which is 
considered as methodically organized actions of adults, aimed at improving and developing the abilities of children and adolescents" [18, p. 221].

This research mostly relates to the state of development of inclusive education, which did not exist as a social phenomenon for a long time in Ukraine, and only recently it has been actively implemented in all spheres of life, in particular in education. On its way, there are a number of issues that need to be solved. First of all, these issues are connected with philosophical, methodological and conceptual understanding of them, professional training of teachers for pedagogical activities with children with special needs; creation of a cultural and educational environment; provision of proper material resources; psychological and pedagogical preparation of parents and students, etc. In this article, we will deal only with some philosophical approaches to the development of inclusive education.

Modern Ukrainian and foreign scholars are investigating a particular problem in different aspects, in especially:

a) describe the situation according to which a person is the highest value (G. Bunch, A. Valleo, S. Goncharenko, R. Gurevich, M. Einsko, A. Kvas , V. Kremen, Sh. Kroker, V. Kudin, J. Sebba, M. Yarmachenko);

b) prove the necessity of human (child) analysis in the context of civilizational changes and the modern paradigm of education (S. Abott, V. Bykov, I. Zyazyun, A. Kolupayev, J. Korbett, I. Rodimenko, O. Romanovsky, P. Saukh);

c) suggest to consider the development of inclusive education in a dialectical relationship with the general education and real needs of children with special needs (V. Bondar, O. Budnyk, O. Gordiychuk, Z. Leniv, D. Lupart, V. Sinyov, P. Foreman, M. Shved, Z. Shevtsiv);

d) searching of ways for developing the general and inclusive education in the context of its humanization and democratization, as well as in the aspect of the spiritual, moral, culturological content of their contents (D. Berret, D. Brown, H. Vasianovych, V. Zhukovsky, P. Clow, M. Peterson, H. Filipchuk, G. Shevchenko);

e) determine the concrete ways, methods and technologies of psychological and pedagogical preparation of the future teacher in the direction of "Inclusive Education" (D. Benfil, I. Bech, V. Bondar, N. Voronska, D. Deppeler, T. Lorman, M. Madj, B. Klosen, G. Piatakova, T. Sac, S. Waldron) and others.

The purpose of the article is to analyze and define the philosophical foundations of the development of inclusive education at its present stage, first of all, the philosophy of personalism and intuitionism.

\section{ANALYSIS AND DisCUSSION}

The concept of "education" in some cases is established in philosophical and pedagogical literature. Especially, the Encyclopedia of Education contains the following definition: "Education is the process and result of assimilating the personality of a certain system of sciences, knowledge, practical skills and experience and related levels of development of its intellectual and cognitive and creative activity, as well as moral aesthetic culture, which, in their totality, determine the social identity and the individual identity of this person" [10, p. 614]. Further, the author of this definition notes that education performs three important functions: mankind development - providing a certain level of knowledge, literacy; the state of emotional and strong-willed sphere, behavioral orientations, readiness to perform various social roles, types of activity, etc.; technological - providing a "base of life"; formation of skills and abilities of labor, public, professional activity; the development of communicativeness in various activities, etc. [10, p. 614-615]. Without denying in general of such an approach, we believe that in today's conditions, the category "education" should be filled with spiritual-value, culturological meanings, as many different scientists are emphasizing [7;12;22].

As to the notion of "inclusive education", it is defined differently:

a) a system of educational services that based on the principle of ensuring the basic right of children to education and the right to study at the place of residence, and predicts the education of a child with peculiarities of psychophysical development under the conditions a comprehensive establishment with compulsory professional psychological and pedagogical support [4, p. 29-30]; 
b) expansion of the participation of all children, especially with the peculiarities of psychophysical development, in the educational process $[13$, p. 8$]$ and others.

From a scientific point of view, any definition has the right to exist, because it in one way or another one reflects a specific phenomenon, in our case, it is a question of a real process of training and education of children with special needs.

The modern state policy in Ukraine in the field of teaching children with peculiarities of development is regulated by the Laws "On Education" (2017), “On Inclusive Education" (2017). Lately, the "legal field" of the development of inclusive education has considerably expanded. The evidence of which is the development of "The National Strategy for the Development of Education in Ukraine for 2012-2021", "The National Action Plan for the Implementation of the UN Convention on the Rights of Persons with Disabilities and the Development of the Rehabilitation System for the Disabled for 20122020" was established, the Concept of Development was examined and partially put into the action of inclusive education (2010). These and other normative documents regulate the real implementation of inclusive education in various teaching and educational establishments of Ukraine.

Though, as B. Bondar fairly notes: "From the point of view of given tasks according to the education of children with peculiarities of development, the conceptual, structural, methodological and organizational principles are fundamentally reformed, the new methodology of education is proclaimed; the interest of the public in the educational needs of students in this category is increasing, and the realization of their opportunities for obtaining and inquiries of alternative school education" [4, p. 10].

At the same time, in our opinion, there is often a lack of explanations of philosophical, methodological principles from the outlined problems in scientific researches. However, from the point of view of the article, as well as taking into account the fact that certain modern scientific concepts have already been studied (philosophical and pedagogical anthropology, hermeneutics, existentialism, synergetics, etc.) [8;9], let us consider those who are also able to increase the level of scientific analysis of a specific problem which is related to the development of inclusive education. Let us, first of all, pay attention to the philosophy of personalism and intuition.

\subsection{Philosophical Personalism}

The main provisions of this direction were proposed by B. Bowne - the American philosopher of the mid-nineteenth and early twentieth centuries. His students were the followers of the teachings in the west: Z. Brightman, E. Kent, W. Kerr, E. Munier, D. Wright, R. Fleling, W. Hocking, V. Stern and others. In Ukraine and Russia, the most famous personalities were M. Berdyaev, M. Loskiy, L. Shestov and others. The focus of personalities is the idea of creative subjectivity of a person, which determines the essence and quality of its real existence. In this regard, Berdyaev wrote: "Creative act is immanent only in figures, the personality who is free and independent in his/her power. The creativity can be called only that which is generated by the original substance, which possesses the power of growth of force in the world. That what is born from the outside, created by the redistribution of substance, is not creativity. The creativity is not a new correlation of the components of the world, creativity is the original act of the personal substances of the world ... Only a personalistic doctrine of the world, for which any being - personal and original and substantive is able to comprehend creativity" [3, p. 360-361].

However, the creativity in the context of personalism is considered and determined through the prism of the spiritual activity of the person. At the same time, it should be noted that the motivation of creativity, its real manifestation is not in the aspect of creativity for the sake of creativity, but first of all for the sake of spiritual and mental development of personality. A particular importance of this idea is taking place nowadays, because of an incredible dynamics, technical processes of life. It deals with that fact, that the individual should not be confused in this situation, he does not have to lose the mental and physical strength to a reasonable opposition to these processes, and he was engaged in his potential resource to the creation of the external and inner world. For example: mastering of modern technology often causes the confusion and even fear of an ordinary child, and of course, without 
talking about a child who has some certain natural defects, and it is quite difficult for her to orient herself in a variety of different signs, symbols, and so on.

It is important in this context to emphasize that each follower, a teacher must be well aware: pedagogical activity is a creative activity, because it is focused on the education of another person, his/her spiritual and cultural, moral and aesthetic development and self-development. On the other hand, the teacher must realize that each child with special development needs owns only her own creative potential and the main point is to reveal it, to direct it to the most active, positive implementation, which is only possible through a scientifically developed methodology and creating an appropriate "I-concept". M. Savchyn notes: the researching of spiritual processes, the creative potential of a person should occur based on interdisciplinary approach, taking into consideration those changes that occur in society, and in the person himself/herself [20, p. 135].

Extremely relevant in the personalization is the idea of uniqueness, independence and inviolability of the individual person. Man is born of space, lives in the space and is charged with its energy. At a certain stage, he/she does not comprehend her being, therefore, is faceless, not capable of creativity. Self-awareness is the first sign that the person separates his/her "I-person" among others, and purely external determinants cannot influence on this "I-person", because of my own experience, it creates herself/himself. A paradoxical situation is created: personality at first glance shows his/her uniqueness, isolation, but in fact, there comes just the moment when it is not "closed", it is not "alienated", but it opens for others, and for himself/herself.

In the context of our research problem, this fact is archival, because a child with special needs usually have "developmental delays", for this, a child needs time and the environment. Too important in this sense is that a person who strives for spiritual growth is not "stuck" in the world of material things, and this is the assertion in the uniqueness that involves the field of active spiritual activity. From this point of view, any reality is individual, personal.

In such an approach, the anthropological influence is rather noticeable, and at the same time, there is a certain denial of existentialism, as, in contrast with representatives of existentialism, the personalists consider the application of scientific research methods in the studying of the essential forces of human, his/her abilities and skills. The theoreticians of personalism understand the risks of human being, which are related to the aggressive and endless attack of technocracy. In view of this, they resort to the development of various theories; one of them is the theory of technosophy, which is intended to replace theosophy and anthroposophy. The main purpose of the theory of technophobia is to study the "wisdom" of technology, but today the technology with artificial intelligence is an objective reality, for each intellectual person it is an obvious fact. Though "the machine tyranny" cannot be overcome, someone should study the tendency of the development of this process, and in a timely manner, influence on the "mitigation" of his actions on the vital functions of a human being.

Obviously, in the context of our analysis, the provisions of personalization about tolerance for those who think do not do the same things as everyone else. Tolerance and empathy on the very basis are a productive idea, because it contains a powerful force of love for the neighbor, humanity, true humanism. Children with special needs need it most of all. They cannot always say this in a frankly way, but they are always waiting for the goodness, the love, the patience of their mentors, teachers, relatives, close people, and they have a burning wish to be clear to others. In this sense, it is important to express feelings and perceptions, your own choice and the will of the individual person. It should be noted that freedom of will is at the heart of personalism. Consecutive, free expression of the personality of his/her aspirations, needs, and interests is its vital purpose.

In this regard, M. Lossky wrote that any substantive figure (like the Monad Leibniz) is a real or potential person. Therefore, this worldview can be called personalism [15, p. 527]. This worldview, in the opinion of the scientist, contains a powerful charge of freedom of the will of the individual person, which represents its independence from the outside world. A human being to a certain extent is free from his/her body, character, from laws defining the content of the process of time and space, even from God (in fact there are atheists). Instead, as M. Loskiy proves, that the freedom of a person's will cannot be understood in his/her absolute, otherwise it can turn into a lack of freedom, the inability to a 
normal co-existence and action with other people, and without it the person only exists, and does not live a full-fledged life. However, the freedom of will obtains formalities, this is a negative freedom. The path is not down to evil, but the path to the goodness up is a true freedom of will.

As for the question of the presence of an individual in a team, it loses any positive meaning when it begins to be standardized, formal. Such an approach, in our opinion, is worth pointing because the children with special needs predict just no standardization, no indifferent attitude to them, and special, trusting, sincere, and on the basis of which human relationships, mutual understanding, real help are building. According to the language of a personalist, it is an "involved existence", which means an active communication, dialogue first of all with the immediate environment (micro-environment), as well as with the whole world (macro environment).

As a child with special needs is often limited in his/her ability to communicate with the macroenvironment, the micro-environment in which he or she should feel free and comfortable is extremely important for her. Such interaction of personalists is also called "exteriorization", hence, as external self-realization. However, more worthy is the inner spiritual world - "internalization". Such a division is, of course, a conditional one, their productivity is manifested in terms of interconnection, interaction. Due to the interaction of these constituents, the movement of "transcendence" is possible, as a movement towards the highest God's values- truth, beauty, kindness. Such awakening of a person in a person the personalists call "personal primordial beginning", which should be based on the pedagogy of kindness and happiness. In this sense, it is appropriate to remind that almost all humanitarian educators (J. A. Comenius, J. Pestalozzi, V. Sukhomlinskiy, I. Ziazyun, etc.) emphasized this approach. In particular, academician I. Zyazun, at the level of self-reflection, wrote: "Something in me was laid by nature, that was calling for the indomitable inner need for decisive action to make someone kind and majestic, lift someone to the top of humanity, which I first felt from my father when he returned from the war, when I with opened arms was flying to heaven, and then I was coming back to my parents' strong arms head" [12, p. 278]. To be open to the needs of the child is a true spiritual, heart-giving art for every follower, teacher, father and mother; this is a great calling of God. It overcomes the child's sense of inferiority, alienation, unclaimedness, and as a result, it overcomes the suspicion, various kinds of negatives, and even - "forgets" the feeling of hostility or aggression.

The philosophy of personalism emphasizes the need to form a holistic personality. Today, this idea is developing by many philosophers, psychologists, and teachers outside this trend (I. Bekh, S. Krymskiy, M. Mamardashvili, H. Filipchuk, N. Chepeliev, etc.). Usually, the beginning in this approach is the idea of creating cultural, moral and aesthetic values, which in their totality are focused on the fact that the person was not "crushed", did not get a "plurality of essence", but was integral and selfsufficient. It usually concerns a person who has special needs of development. All the content of education should work on it $\mathrm{H}$. Filipchuk writes that such an approach stimulates "... to establish the cultural orientation of the content of education despite its technocratic, informational, and rational way. First of all, one should proceed from the assumption that education at all times, in the period of the reformist era remains an integral part and reflection of the culture itself, and the general, professional, and civic culture is the most important indicator of individual's assessment" [23, p. 6].

The basic points of the philosophy of personalization are distinguished and have extremely important methodological significance for studies that are conducted directly in the field of inclusive education.

Firstly, they direct the researcher to learn not only the biological, social, psychophysical, but also the spiritual factors of the development of a person who has special needs.

Secondly, they encourage to analyze the creative potential, creative peculiarities of each individual person, to identify among them the main ones, and, on this basis, to involve them in "related work" (H. Skovoroda), to self-knowledge and self-development.

Thirdly, they allow, based on a well-organized pedagogical experiment, to comprehend the uniqueness and eccentricity of each child with special educational needs, motivation to strengthen the will and character, development of the intellectual and sensory sphere. 
Fourthly, they help to determine the most focused and productive forms of communication, during which the principle of internalization is realized and the spiritual world of the subject is revealed.

Finally, they allow to influence the formation of a holistic person positively, sometimes even overcome its internal resistance and reluctance to be perfected physically and / or spiritually.

\subsection{The PHILOSOPHY OF INTUITIONISM}

This tendency, like the previous one, also started in the middle of the nineteenth century, and in its development passed several stages:

1) empirical, based on which the biological instinct was based;

2) sensational in which a sensual form of cognition - sensation and perception was entrusted;

3) intellectual - is characterized by an expression of mental factors;

4) critical, dominated by the hidden and unconscious principles of creativity [22, p. 299-300].

The main representatives of the direction were H. Bergson, J. Hamann, E. Hartmann, E. Husserl, B.Croche, M. Losskiy, J. Moore, F. Schelling and others.

Let us consider shortly the leading ideas of the theory of intuitionism, its characteristic features and what it actually provides for the study of the problems of inclusive education.

M. Losskiy in his work “Explanation of Intuition" wrote: “... This theory of knowledge, as it should be, explores only the processes of knowledge" [16, p. 104]. Then the philosopher explains, " intuition opens and deletes the wrong premise of the gap between the subject of knowledge and the object being known ..." [16, p. 326]. The scholar noted that such an approach was characteristic of theories of knowledge of individualistic empiricism, pre-Kantian rationalism and Kantian criticism.

Especially, R. Descartes, B. Spinoza argued that intellectual intuition was the supreme act of intelligent cognition. "Under intuition, I understand not belief in the unsteady testimony of feelings and not a misleading judgment of a disordered representation, and understanding (conceptus) of a clear and careful mind", wrote R. Descartes, "so easy and clear that there is no doubt that we understand, or that the same, undoubted understanding of a clear and careful mind, which is generated only by the light of reason and is simpler, therefore, more reliable than deduction itself ..." [11, p. 84]. In his turn, B. Spinoza argued that this kind of knowledge (intuition) leads to an adequate knowledge of things [19, p.439]. However, the theorists of intuition, without denying the categorical form of the above-mentioned thoughts, consistently substantiated and advocated the idea that only rational (intellectual) cognition is not enough. What did the representatives of intuition understand, and how was the intuitive knowledge and cognition explained?

Firstly, H. Bergson, as one of the most prominent representatives of the field, expressed the view that intuition is independent of any links with practical interests, free from the views and methods recommended by practice. Intuition is a direct comprehension of the essence of things. It recognizes life as life, not as a mechanical style that immortalizes and distorts the process of its development. Intelligence and intuition, as explained the scientist, are not two consecutive stages - lower and higher, but two classes of knowledge that develop in parallel. They mutually determine and complement each other. Their source is the experience, and this genetic and empirical unity of intellect and intuition, the unity of their origin contributes to the profound knowledge of reality. Though, according to $\mathrm{H}$. Bergson, intuition "is an instinct that is selfless, as conscious of itself, able to think about its subject and extend it indefinitely" [1, p. 160].

Secondly, only intuition can perform the task of philosophy to know everything alive in the absolute, though, it does not stop at relative knowledge. It is because it captures reality directly, without the aid of analysis, without the help of symbols. "I think", wrote H. Bergson, "that intuition plays in the field of speculation the same role which was played by Socrates' demon in the practical life. In other words, it appears in this form for the first time, and in the same form it will be most clearly displayed in the future ..." [2, p. 4-5]. Undoubtedly, there is a certain exaggeration, even absolutism, but at the same time there is accentuation on the important role which is played by intuition in the process of cognition and real life of the individual person. 
Thirdly, the intuition is a deeply individualized phenomenon, because in every individual, it is developed at different levels, and it is manifested differently. Intuition is a certain kind of thinking, this ability to comprehend the truth through direct perception of it, undocumented (unconscious) explanation. At the same time, as H. Bergson notes, the level of intuition in a person can change, it depends on its professional and personal development, strong-willed efforts, etc. At this point, it should be noted: if the researcher usually chooses a topic of study on those or other issues of inclusive education is purely intuitive, then a teacher who works with children with special needs, almost every day meets with the problems that require him an immediate, spontaneous reaction, lightning making a decision. In addition, he has to be ready for it that requires his constant self-improvement and selfdevelopment.

It is logical from the point of view that the representatives of intuitionism refuse purely from intellectual method of cognition of reality, especially as regards the internal, spiritual world of a human, his relations with other people. Instead, the main thing is proclaimed - the method of intuitionism, which, in their opinion can fathom to a place where the mind does not fathom into the depths of the real being. The thinking here is this kind: though the scientific knowledge unequivocally serves as a practice, it is one-sided, because in our world there are many things that are deprived of "empirical interest".

The intellect does not observe, it is related to practice, it deliberately "selects" what it is useful and necessary. In such field as an inclusive education, cooperation with children with special needs - selfinterest is in general unacceptable, and indeed, here not everything can be subjected to "universal world". That is why; intellectual cognition in some cases is external and formal, and therefore dangerous, because the desired one may appear to be valid. From the point of view of theoreticians of intuitionism, the method of intellectual cognition is particularly ineffective and dangerous, where it refers to the movement and development of the child, though this development is dynamic, controversial, that requires the studying of deep psychophysical, spiritual factors, the specific conditions and development of children with special needs. In contrast, theoreticians of intuition give high praise to the rationalist method of cognition in questions of the interrelation of language and thinking.

Theoreticians of intuitivism are critical of the role of concepts and their definition in modern science. This criticism is focused not only at the fact that these or other concepts are often not essential but descriptive and illogical character. Their reservations relate to the fact that concepts turn into something "frozen", and therefore do not allow one or another phenomenon to be recognized in the movement, the dynamics, do not give an opportunity to see the development trends selected for the analysis of the problem. In fact, if we analyze the content of the concepts offered by some authors in relation to the development of inclusive education, it is easy to verify the truthfulness of the views of the theorists of intuitionism. The American scientist Tim Lawman had every reason to say: "The term" inclusive education "is interpreted differently, sometimes in the sense of the very opposite of what it means" [14, p. 3].

There is an interesting a thought about the intuitionism of a human consciousness as "indivisible continuity", "impulse", possessing creative potency, the ability to different, fluid, and relatively stable transformations. According to $\mathrm{H}$. Bergson, the consciousness of the subject, which is a manifestation of "super consciousness" only uses the brain as its receptacle, weapon, shelter, form of being, just as the artist uses a canvas and paints to realize his intention. The philosopher wrote about this: everything happens as though the mind comes from the brain, and it seems that a detailed conscious activity is formed by detailed brain activity. Nevertheless, in reality, consciousness does not flow out of the brain. Concerning the fact that consciousness "does not follow" from the brain, today it is a fulfilled fact, instead, it should be emphasized on another: the consciousness should be so-called "socialist vector", which Bergson ignores in some cases.

According to the inclusion problem, this factor is especially important. There are many discussions where the children with special needs should be taught: in the establishments of general secondary education or special education. Life proves the indisputable fact: if you really adhere to the humanistic 
principles and take care of the development of consciousness of children with special needs, then the appropriate conditions for socialization should be made [6]. In our opinion, such conditions should be organized in the establishments of general secondary education. Moreover, this process should be studied extensively and analyzed in order to improve inclusive education. It is possible and necessary to do it on the basis not only of material support, but also on the basis of "open", truly human morality and spirituality.

The analysis of the basic provisions of the philosophy of intuitionism makes it possible to determine their methodological significance for scientific research in the inclusion education.

Firstly, one of the upcoming principles in the choice of the subject of the study of inclusive education should be non-conjunct themes that can satisfy only the author of the study and those who solve the urgent psychological and pedagogical problem.

Secondly, the philosophy of intuitionism proves the need for a detailed logical definition of concepts, definitions that would substantially reflect the meaning of a particular psycho-pedagogical phenomenon or process.

Thirdly, though the intuition is the property of the human spirit, the philosophy of intuitionists focuses the researcher on the application in the study along with such philosophical and pedagogical methods as analysis and synthesis, induction and deduction, etc., and intuitive method.

Fourthly, a strong methodological significance is also given to the philosophy of intuitionism about human communication and real help for children with special needs in mastering language, sign systems and others like that. Such an approach focuses on finding ways and means of disclosing the child's soul, his/her trust to those who are surrounding her.

Finally, though an important place in the philosophy of intuition is the idea of consciousness and self-consciousness of a person, and they need fundamental researches related to the real conditions of its socialization.

\section{CONCLUSIONS}

In view of the above-mentioned, we can draw the following conclusions:

1. Contemporary inclusive education as a component of general education requires a substantial reform to meet the challenges faced by personality and society.

2. In today's educational space, there are still stereotypical ideas about teaching children with the needs of psychophysical development. This contradicts the strategies for the inclusion and implementation of the best world experience in the educational process of educational institutions. Therefore, there is a need for a new philosophy in society according to the attitude towards people with disabilities.

3. The efficiency of the inclusive process depends largely on teachers. Their beliefs are reflected in attitudes towards students with certain disruptions in development, which greatly affect their willingness to work in an inclusive environment (S. Main, D.J. Chambers and P. Sarah, 2016) [24].

4. Among the various philosophical theories and concepts, the philosophy of personalism and intuition, which have a powerful methodological potential for analyzing contemporary problems of inclusive education, occupy an important place.

\section{REFERENCES}

[1] Bergson H. Creative Evolution. Russkaia Mysl, Moscow - St. Petersburg, 1914. (in Russian)

[2] Bergson H. Philosophical Intuition. New Ideas in Philosophy, 1 (1912), 1-28. (in Russian)

[3] Berdyaev N.A. The meaning of creativity. In: Philosophy of Freedom. The Meaning of Creativity. Pravda, Moscow, 1989, 254-534. (in Russian) 
[4] Bondar V.I. Inclusive education as a socio-pedagogical phenomenon. Ridna Shkola, 3 (2011), 10-14. Available at: http://nbuv.gov.ua/UJRN/rsh_2011_3_4 (in Ukrainian)

[5] Budnyk O. Inclusive Education. Publisher G. Kushnir, Ivano-Frankivsk, 2015. (In Ukrainian)

[6] Budnyk O. Inclusive education: socio-pedagogical context of the problem. In: Zasenko V.V., Kolupayeva A.A. (Eds.) Education for people with special needs: ways of development, vol. 13. "Nasha Drukarnia", Kyiv, 2017, 71-80. (in Ukrainian)

[7] Vasianovych H., Onyshchenko O. Noology of a Personality. Spolom, Lviv, 2012. (in Ukrainian)

[8] Vasianovych H.P. Methodological contexts of pedagogical science at the present stage of its development. In: Selected Works: in 7 volumes, vol. 7. Norma, Lviv, 2015, 164-186. (in Ukrainian)

[9] Vasianovych H., Logvinenko V. Social work: methodological aspects of research In: Krivatchuk L.F., Nagirniak M.Ya. (Eds.) Materials of IV International scientific and practical conference "Social work: formation, prospects, development", Lviv, Ukraine, May 24-25, 2018, SPOLOM, Lviv, 2018, 151-162. (in Ukrainian)

[10] Goncharenko S.U. Education. In: Kremen V.G. (Ed.) Encyclopedia of Education. Yurinkom Inter, Kyiv, 2008, 614-616. (in Ukrainian)

[11] Descartes R. Rules for the guidance of the mind. In: Works in 2-vol., Vol. 1. Mysl', Moscow, 1989, 77-153. (in Russian)

[12] Ziaziun I.A. Pedagogy of Kindness: Ideals and Realities. MAUP, Kyiv, 2000. (in Ukrainian)

[13] Kulyk V. Organization of teaching children with special educational needs: methodical recommendations. Defectologist, 11 (2010), 8-12. (in Ukrainian)

[14] Lorman T. Seven pillars of inclusive education: how to move from the question "why?" To the question “how?" Defectology, 3 (2010), 3-11. (in Ukrainian)

[15] Lossky N.O. Freedom of the will. In: Selected Works. Pravda, Moscow, 1991, 484-597. (in Russian)

[16] Lossky N.O. Justification of intuitivism. In: Selected Works. Pravda, Moscow, 1991, 13-337. (in Russian)

[17] Mounier E. A Personalist Manifesto. Respublika, Moscow, 1999. (in Russian)

[18] Ryus J. Progress of modern ideas: A panorama of modern science. Trans. from French by V. Shovkun. Osnovy, Kyev, 1998. (in Ukrainian)

[19] Spinoza V. Ethics. In: Selected Compositions in 2 vol., Vol. 1. State publishing house of political literature, Moscow, 1957, 317-618. (in Russian)

[20] Savchyn M.V. Spiritual Potential of Human. Misto NW, Ivano-Frankivsk, 2010. (in Ukrainian)

[21] Savchyn M.V. Ability of Personality. VC "Academy", Kyiv, 2016. (in Ukrainian)

[22] Filipchuk H.H. National-creativity of Education. Zelena Bukovyna, Chernivtsi, 2014. (in Ukrainian)

[23] Lyons W.E., Thompson S.A., Timmons V. 'We are inclusive. We are a team. Let's just do it': commitment, collective efficacy, and agency in four inclusive schools. International Journal of Inclusive Education, 20 (8) (2016), 889-907. doi: 10.1080/13603116.2015.1122841

[24] Main S., Chambers D.J., Sarah P. Supporting the transition to inclusive education: teachers' attitudes to inclusion in the Seychelles. International Journal of Inclusive Education, 20 (12) (2016), 1270-1285. doi: 10.1080/13603116.2016.1168873

[25] Hunter W.C., Elswick S.E., Casey L.B. Efficient Wraparound Service Model for Students with Emotional and Behavioral Disorders: A Collaborative Model for School Social Workers and Teachers. Children $\mathcal{E}$ Schools, 40 (1) (2018), 59-61. doi: 10.1093/cs/cdx030

Address: Hryhoriy Vasianovych, Lviv State University of Life Safety, 35, Kleparivska Str., Lviv, 79000, Ukraine;

Olena Budnyk, Vasyl Stefanyk Precarpathian National University, 57, Shevchenko Str., IvanoFrankivsk, 76018, Ukraine.

E-mail: wasianowych@ukr.net; olena.budnyk@pu.if.ua

Received: 17.12.2018; revised: 05.02.2019. 
Васянович Григорій, Будник Олена. Філософські засади досліджень розвитку інклюзивної освіти. Журнал Прикарпатського університету імені Василя Стефаника, 6 (1) (2019), 9-18.

У статті на основі першоджерел досліджено філософські засади сучасної інклюзивної освіти. Представлено змістову характеристику поняття “інклюзивна освіта", доведено необхідність іï впровадження. Акцентовано на двох основних філософських засадах іï розвитку: персоналізму й інтуїтивізму. Такий підхід зумовлений тим, що в сучасних дослідженнях з окресленої проблематики переважно домінують раціоналістичні методологічні підходи, натомість ірраціональналістичні теорії часто залишаються поза увагою. У нашому аналізі і трактуванні філософія персоналізму виконуе важдиву методологічну роль тому, що допомагає з`ясувати сутність унікальності і неповторності кожної дитини, яка має особливі потреби та визначити реальні шляхи їі духовного і психофізичного розвитку. Філософія інтуїтивізму орієнтуе на дослідження питань, що пов'язані із формуванням свідомості особистості, яка має особливі потреби. Тому авторами доведено необхідність застосування інтуїтивного методу дослідження, який дозволяє активно сприяти комунікації суб'єктів взаємодії, розкривати їх духовний потенціал, здійснювати пошук шляхів формування мислення у дітей 3 особливими потребами, активно застосовуючи при цьому мову, культуру, мистецтво.

Ключові слова: інклюзивна освіта, людиноцентризм, дитиноцентризм, людина з особливими потребами, освітній процес, філософія інклюзії. 